\title{
PENGEMBANGAN ASPEK KEUANGAN INDUSTRI OLAHAN IKAN CV. BENING JATI ANUGRAH PARUNG BOGOR, JAWA BARAT
}

(Program Pengabdian Kepada Masyarakat di CV. Bening Jati Anugrah Parung, Jawa Barat)

\author{
Nawiyah \\ Politeknik APP Jakarta \\ Iyahapp79@gmail.com
}

\begin{abstract}
ABSTRAK
Program pengabdian kepada masyarakat yang mengambil objek usaha olahan ikan di CV. Bening Jati Anugrah daerah Parung, Jawa Barat ini bertujuan untuk mengembangkan aspek keuangan. Hasil identifikasi masalah di lapangan yaitu ditemukan adanya kekurangan pemahaman tentang konsep dasar keuangan yang ada di dalam industri kecil ini terkait dengan pembukuan dan system informasi keuangan yang masih jauh dari kesempurnaan. Kegiatan yang dilakukan oleh tim pengabdian adalah survei lokasi usaha industri olahan ikan CV. Bening Jati Anugrah kemudian tim pengabdian memberikan pengetahuan tentang konsep dasar keuangan yang jelas dan system informasi keuangan yang bagus dan mudah diikuti oleh orang lain. Penetapan penggunaan pembukuan serta membantu cara penggunaan pemilihan aplikasi yang tepat. Dengan program ini diharapkan pengelolaan industri olahan ikan CV. Bening Jati Anugrah dapat berkembang lebih baik dan dapat bersaing dengan produk yang sejenis.
\end{abstract}

Kata kunci : Konsep dasar keuangan, Industri kecil, sistem informasi keuangan

\begin{abstract}
This community service program that takes the object of fish processing business in CV. Bening Jati Anugrah Parung, West Java aims to develop financial aspects. The results of the identification of problems in the field, namely the discovery of a lack of understanding of the basic financial concepts that exist in this small industry related to accounting and financial information systems that are still far from perfection. The activity carried out by the service team was a survey of the location of CV. Clear Teak Anugrah then the dedication team provided knowledge about clear basic financial concepts and good financial information systems that were easy for others to follow. Determination of the use of bookkeeping and help how to use the right application selection. With this program it is expected that the management of the processed fish industry CV. Bening Jati Anugrah can develop better and can compete with similar products.
\end{abstract}

Keywords: Basic concepts of finance, small industries, financial information systems

\section{A. PENDAHULUAN}

Daerah Parung Bogor adalah sebuah kecamatan di Kabupaten Bogor, Provinsi Jawa Barat, Indonesia. Parung memiliki sebuah pasar tradisional yang aktif 24 jam, Di Parung juga terdapat beberapa Objek Wisata yang terkenal, yaitu Taman Pemandian Air Panas Tirta Sanita Gunung Kapur, Batu Tapak (fosil sejarah) di daerah Cidokom. Tempat Ziarah yang terkenal :

1. Makam Raden Demang Arya di Waru Jaya

2. Makam Syeikh Mbah Dempung di Bojong Indah 
3. Makam Mbah Dengkong di Kp. Jeletreng Ds. Cogreg

4. Makam H. Mawi di Gang Amsar Kp. Bojong Sempu Indah

Parung Bogor memiliki luas 73,76 Km², dengan jumlah penduduk 143.174 (2017) memiliki 9 desa/Kelurahan. Masyarakatnya mempunyai mata pencaharian mayoritas berdagang khususnya sayuran, ada juga sebagian sebagai pengrajin kayu. Masyarakat Parung sudah mengarah ke nuansa perkotaan mengingat penduduknya banyak yang berjualan di pusat kota, Daerah Parung juga memiliki akses mobilitas yang sangat tinggi dan juga terdapat banyak sekolah baik dari tingkat dasar sampai menengah. Daerah Parung juga memiliki akses yang sangat strategis bila ingin ke pusat Kota Jakarta karena berada di tengah perbatasan antara Kota Administratif Depok dan Jakarta Selatan (Wikipedia, 2019).

Usaha Kecil Menengah (UKM) merupakan salah satu bagian penting dari perekonomian suatu negara ataupun daerah asal, tidak terkecuali di Indonesia. Usaha Kecil dan Menengah (UKM) merupakan usaha yang banyak dilakukan banyak orang di Indonesia. UKM mulai berkembang pesat setelah terjadinya krisis ekonomi berkepanjangan pada tahun 1997-1998. Hal ini berdampak banyaknya terjadi PHK oleh perusahaan-perusahaan besar. Banyak karyawan yang di PHK membuat sebagian dari mereka yang mulai mengembangkan berbagai usaha seperti usaha jual beli, bisnis pengolahan dan jasa. Usaha Kecil Menengah di anggap sebagai penyelamat perekonomian Indonesia ketika krisis moneter. UKM dianggap sebagai jalan keluar dan penyelamat ekonomi karena UKM dapat berperan untuk mengurangi pengangguran dan mampu menyerap tenaga kerja. Selain itu Usaha Kecil Menengah juga banyak berkontribusi terhadap pendapatan daerah maupun negara. Adapun ciri-ciri Usaha Kecil Menengah adalah modal kecil serta resiko tidak terlalu tinggi namun keuntungan yang besar.

Salah satu Usaha Kecil Menegah (UKM) di daerah Parung Bogor adalah industri olahan Ikan CV. Bening Jati Anugrah. Usaha ini mulai dirintis sejak Februari 2007 dengan nama usaha “ Bening Jati Anugrah”. Dalam perjalanan usahanya, Bening Jati Anugrah dengan merk produk Bening Food, dengan tenaga kerja yang terlibat saat ini mencapai 22 orang berlatar pendidikan SMP sampai dengan tingkat S1 ( sarjana ). Yang menjadi nilai jual dari olahan CV. Bening Jati Anugrah tidak lain adalah makanan siap saji olahan ikan dengan mengedepankan mutu. Mutu yang terkandung dalam olahan ikan ini sangat diperhatikan oleh produsen karena makanan merupakan kebutuhan 
primer dari konsumen. Faktor yang diperhatikan oleh produsen antara lain berupa kadar protein, kadar minyak dan kadar karbohidrat, juga meliputi faktor yang berpengaruh pada nilai gizi dan keamanan/kesehatan pangan, seperti adanya zat beracun (toksin), komponen/logam berbahaya seperti $\mathrm{Cu}, \mathrm{Pb}$ dan $\mathrm{Hg}$, bakteri patogen, mikotoksin dan sebagainya (PT. Dharma Niaga, 1992).

\section{B. LANDASAN TEORI}

\section{Perencanaan Strategis}

Pimpinan suatu perusahaan, setiap hari berusaha mencari cara atau kesesuain antara usaha yang dilakukan dengan faktor-faktor internal yang dimiliki perusahaan dan kekuatan-kekuatan eksternal baik itu peluang ataupun ancaman suatu pasar. Kegiatannya meliputi pengamatan secara hati-hati dari para pesaing, peraturan yang berlaku, tingkat daya beli konsumen, siklus bisnis dan keinginan dan harapan konsumen, serta faktor-faktor lain yang dapat mengidentifikasi peluang dan ancaman (Rangkuti, 2008).

Suatu perusahaan dapat mengembangkan strategi untuk mengatasi ancaman eksternal dan merebut peluang yang ada. Proses analisis, perumusan dan evaluasi strategi-strategi itu disebut perencanaan strategis. Tujuan utama perencanaan strategis adalah agar perusahaan dapat melihat secara objektif kondisi-kondisi internal dan eksternal, sehingga perusahaan dapat mengantisipsi perubahan lingkungan eksternal. Dalam hal ini dapat dibedakan secara jelas, fungsi manajemen, konsumen, distributor, dan pesaing. Jadi perencanaan strategis penting untuk memperoleh keunggulan bersaing dan memiliki produk yang sesuai dengan keinginan konsumen dengan dukungan yang optimal dari sumber daya yang ada.

\section{Strategi Keuangan}

Dalam suatu usaha yang sudah berjalan, srategi sangat diperlukan baik usaha yang masih berskala mikro maupun usaha yang sudah makro. Strategi dimaksud adalah untuk mensiasati bagaimana usaha ini dapat berjalan atau berkembang bahkan mungkin maju di masa yang akan datang. Untuk keberlangsungan hidup suatu usaha tentunya salah satu faktor penentu adalah dari sisi keuangan perusahaan. Dimana faktor ini menjadi sangat penting dalam mengelola usaha baik dari mulai usaha itu tumbuh, mulai berkembang sampai usaha itu maju. Berhasilnya suatu bisnis atau usaha 
dapat dilihat dari kemampuan usaha menghasilkan laba bersih (Rangkuti, 2008). Halhal yang harus diperhatikan untuk mencapai hal tersebut adalah :

a. Membangun sistem manajerial yang dapat mengantisipasi risiko

b. Memiliki ketersediaan modal, portofolio bisnis yang seimbang dan posisi bersaing

c. Memiliki tim manajemen yang tangguh sehingga dapat mengantisipasi semua perubahan yang terjadi.

\section{Pengelolaa Keuangan}

Setiap usaha yang dijalankan harus memiliki Visi dan Misi yang jelas, agar usaha dapat berjalan sesuai dengan tujuan yang ingin dicapai pemilik perusahaan. Salah satu misi yang harus berjalan baik adalah adanya pengelolaan dalam segala aspek manajemen, misalny aspek produksi, aspek sumber daya manusia, aspek keuangan, aspek pemasaran dan lainnya.

Pengelolaan keuangan menjadi sangat penting karena dengan adanya sistem yang baik maka keberhasilan pengelolaan usaha akan lebih teratur dan terintegrasi dengan baik. Dengan adanya sistem keuangan yang teratur akan memberikan manfaat bagi manajemen perusahaan misalnya memberikan informasi kepada manajemen dalam menjalankan usahanya. Beberapa kegunaan akuntansi manajemen adalah mengendalikan kegiatan perusahaan, memonitor arus kas, dan menilai alternatif dalam pengambilan keputusan. Pengendalian perusahaan melalui aktivitas yang dijalankan (activity based management) merupakan tren baru dalam akuntansi manajemen (Kinanti Geminastiti, 2016).

\section{METODE PELAKSANAAN}

Metode yang kami gunakan adalah menggunakan metode survei yang dilakukan selama beberapa kali pendampingan, kemudian tim pengabdian akan menganalisis kebutuhan dari sasaran pengabdian ini. Setelah itu tim pengabdian akan melakukan pertemuan dan pendampingan dengan salah satu pemilik bisnis olahan ikan serta para karyawan dan tim pengabdian masyarakat akan fokus pada perbaikan system keuangan yang modern, ruang lingkup system keuangan dan sarana yang akan digunakan untuk perbaikan lebih sempurna. Permasalahan yang dihadapi mitra adalah terbatasnya system yang digunakan sehingga terkadang informasi yang dibutuhkan terbatas. Pemecahan masalah yag disarankan dari tim pengabdian ini adalah memberikan 
pendampingan terkait aspek keuangan dan system informasi keuangan yang dibutuhkan.

Sasaran dari kegiatan ini adalah salah satu pemilik yaitu bernama Ibu Purnani sangat tertarik untuk memenuhi atau menyempurnakan system informasi keuangan yang dibutuhkan sehingga produk olahan ikan yang dihasilkan dapat berkembang lagi khususnya system informasi keuangan. Metode kegiatan yang dilakukan adalah dengan memberikan materi terkait pentingnya system informasi keuangan yang bagus dan modern agar usaha lebih berkembang dimasa yang akan datang.

\section{HASIL DAN PEMBAHASAN HASIL}

\section{Hasil}

Pada awal survey kami dati tim pengabdian masyarakat dibagi ke dalam 2 tim, yaitu tim keuangan dan tim pemasaran. Tim keuangan memberikan pendampingan langsung kepada karyawan yang menangani keuangan usaha. Tim pemasaran memberikan pendampingan kepada karyawan yang menangani langsung pemasaran di CV. Bening Jati Anugrah. Khusus tim keuangan memfokuskan pemberian penyuluhan mengenai pengelolaan keuangan dengan system yang terintegrasi kepada beberapa bagian misalnya dengan bagian pemasaran dan produksi.

Kunjungan pertama tim penyuluh melihat dahulu sistem keuangan yang telah digunakan, ternyata sudah berbasis komputer tetapi baru dengan microsoft Excel dan belum terintegrasi dengan bagian yang lain. Tim penyuluh menyarankan menggunakan aplikasi keuangan yang sudah modern dan dapat digunakan dengan cepat dan terintegrasi. Kunjungan kedua tim keuangan pun menjelaskan manfaat dari penggunaan aplikasi keuangan yang sudah jadi tersebut misalnya, pekerjaan lebih mudah karena karyawan tinggal entry data saja apa yang menjadi siklus akuntansi seperti pengeluaran belanja bahan baku, pembelian bumbu-bumbu, penggunaan tenaga kerja dalam periode tertentu seperti 1 hari atau mungkin 1 minggu, penggunaan bahan bakar, penggunaan listrik dll. Kunjungan ketiga penyuluh menjelaskan dengan aplikasi tersebut bisa langsung membuat rekapan dari semua jenis kegiatan perbagian dan mempermudah dalam pembuatan laporan seperti laporan bulanan bahkan laporan tahunan yang terdiri dari Laporan Keuangan Neraca, Laporan Rugi Laba atau pun Laporan Perubahan Modal. Kunjungan keempat penyuluh menjelaskan untuk bagian lain dari aplikasi tersebut karena sudah terintegrasi bisa dilihat pemakaian biaya misalnya untuk bagian 
pemasaran bisa melihat biaya promosi yang menjadi beban usaha setiap bulan dan untuk bagian produksi bisa melihat hasil produksi yang tercapai dalam 1 bulan berjalan, atau hasil akhir produksi dalam 1 tahun.

Pada kunjungan kelima dan keenam tim pengabdian masyarakat menawarkan beberapa aplikasi akuntasi yang bisa diterapkan di CV. Bening Jati Anugrah, misalnya General Ledger, Accounting Software, Ez Track Money dan aplikasi buatan sesuai keinginan si pengguna. Pada kedua kunjungan tersebut tim pengabdian masyarakat memberikan arahan dan bimbingan bagaimana penggunaan aplikasi tersebut serta fungsi-fungsi bawaan dari aplikasi akuntansi yang diajarkan. Serta hasil akhir dari aplikasi akuntansi tersebut, serta menjelaskan pula apa saja output yang lain dari semua aplikasi yang ditawarkan. Pada kunjungan ketujuh dan delapan tim pengabdian masyarakat masih memberikan bimbingan mengenai penggunaan dari aplikasi akuntansi yang diinginkan CV. Bening Jati Anugrah.

Pemilik usaha CV. Bening Jati Anugrah sangat tertarik untuk menggunakan aplikasi keuangan yang dijelaskan oleh tim pengabdian masyarakat Politeknik APP, khususnya dari Aplikasi akuntansi buatan tim pengabdian masyarakat, kenapa bisa tertarik ? pertama biaya yang dikelurkan sedikit hanya untuk pembelian alat-alat tambahan saja seperti software, kedua aplikasi dimaksud dijamin dalam penggunaanya bila ada kerusakan tim pengabdian masyarakat yang membetulkannya. Aplikasi sangat mudah karena masih menggunakan Microsoft Excel dengan menggunakan formula yang difungsikan sedemikian rupa. Ketiga yang merupakan kelebihan aplikasi ini adalah sangat mudah dipelajari dan sangat sederhana karena menggunakan Microsoft Excell. Sangat disayangkan keputusan tersebut tidak didukung oleh anak pemilik usaha CV. Bening Jati Anugrah karena beliau sudah lebih dahulu memesan sebuah aplikasi General Ledger kepada temannya. Maka keputusan pemilik usahapun akhirnya mengikuti kemauan putranya karena sudah terlebih dahulu memesan aplikasi tersebut. Putra pemilik usahapun yang mengendalikan semua proses keuangan di CV. Bening Jati Anugrah.

Penyuluhan yang dilakukan oleh tim pengabdian masyarakat tidak menjadi sia-sia, karena para karyawan sudah lebih mahir dalam penggunaan aplikasi akuntansi yang sudah terintegrasi. Mereka khususnya di bagian keuangan sudah bisa mengoperasikan sebuah system akuntansi yang sudah terintegrasi dengan bagian lain, yang hasil akhir dari aplikasi akuntansi tersebut tidak hanya Laporan Keuangan perusahaan tetapi juga 
melaporkan administrasi bagian-bagian lain yang saling terintegrasi dengan baik. Laporan keuangan yang berupa Neraca, Perubahan Modal dan Rugi Laba merupakan sarana yang digunakan manajemen dalam pengambilan keputusan dan merupakan data terpenting dalam sebuah perusahaan.

\section{Pembahasan}

Kegiatan yang dilakukan tim pengabdian masyarakat mulai dari persetujuan mitra, pemahaman dan pemberian materi untuk perbaikan industri olahan ikan terkait aspek keuangan dan system informasi keuangan serta perbaikan yang diperlukan. Namun dalam kegiatan ini kami tidak terlalu mudah untuk pengambilan gambar dan dokumentasi dikarenakan waktu kami memberikan penyuluhan bersamaan dengan waktu proses produksi pengolahan ikan. Kami pun tidak diperbolehkan mengambil foto terlalu banyak karena mengganggu proses produksi. Pemecahan masalah yang kita lakukan pertama adalah sosialisasi terhadap mitra dilanjutkan dengan kegiatan yang sudah diagendakan. Pemecahan masalah yang kedua adalah memberikan edukasi terkait dengan pentingnya system keuangan serta solusi untuk perbaikan dimasa yang akan datang. Hal ini sangat diperlukan dalam kegiatan bisnis karena bertujuan sebagai sarana penyedia informasi dari produk olahan ikan CV. Bening Jati Anugrah baik bagi kepentingan manajemen ataupun pihak luar seperti investor. Selanjutnya tim pengabdian masyarakat Politeknik APP Jakarta membantu dalam proses perbaikan system keuangan baik berupa saran dan pemilihan system informasi yang harus digunakan. Tetapi pemilihan system masih menjadi hal yang diperbincangkan antara pemilik usaha CV. Bening Jati Anugrah karena banyaknya pilihan aplikasi yang akan digunakan dan pada akhirnya pemilik CV Bening Jati Anugrah mengikuti keinginan putranya karena beliaulah yang mengelola dan memegang pekerjaan keuangan tersebut. Adapun beberapa dokumentasi yang menjadi hasil tim pengabdian kepada masyarakat ketika pendampingan di CV. Bening Jati Anugrah adalah sebagai berikut :
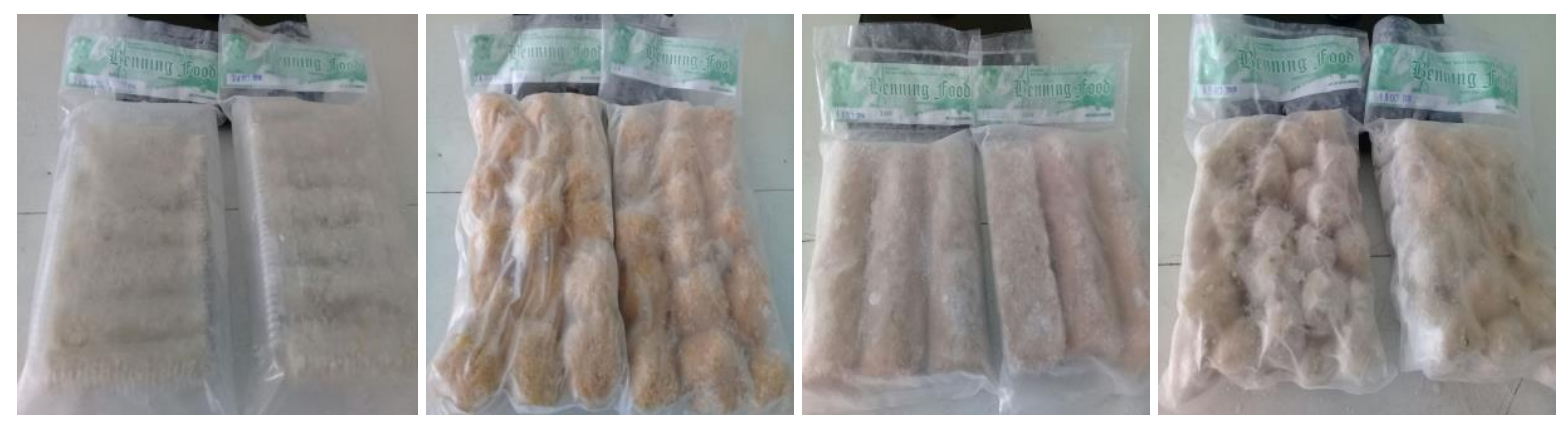

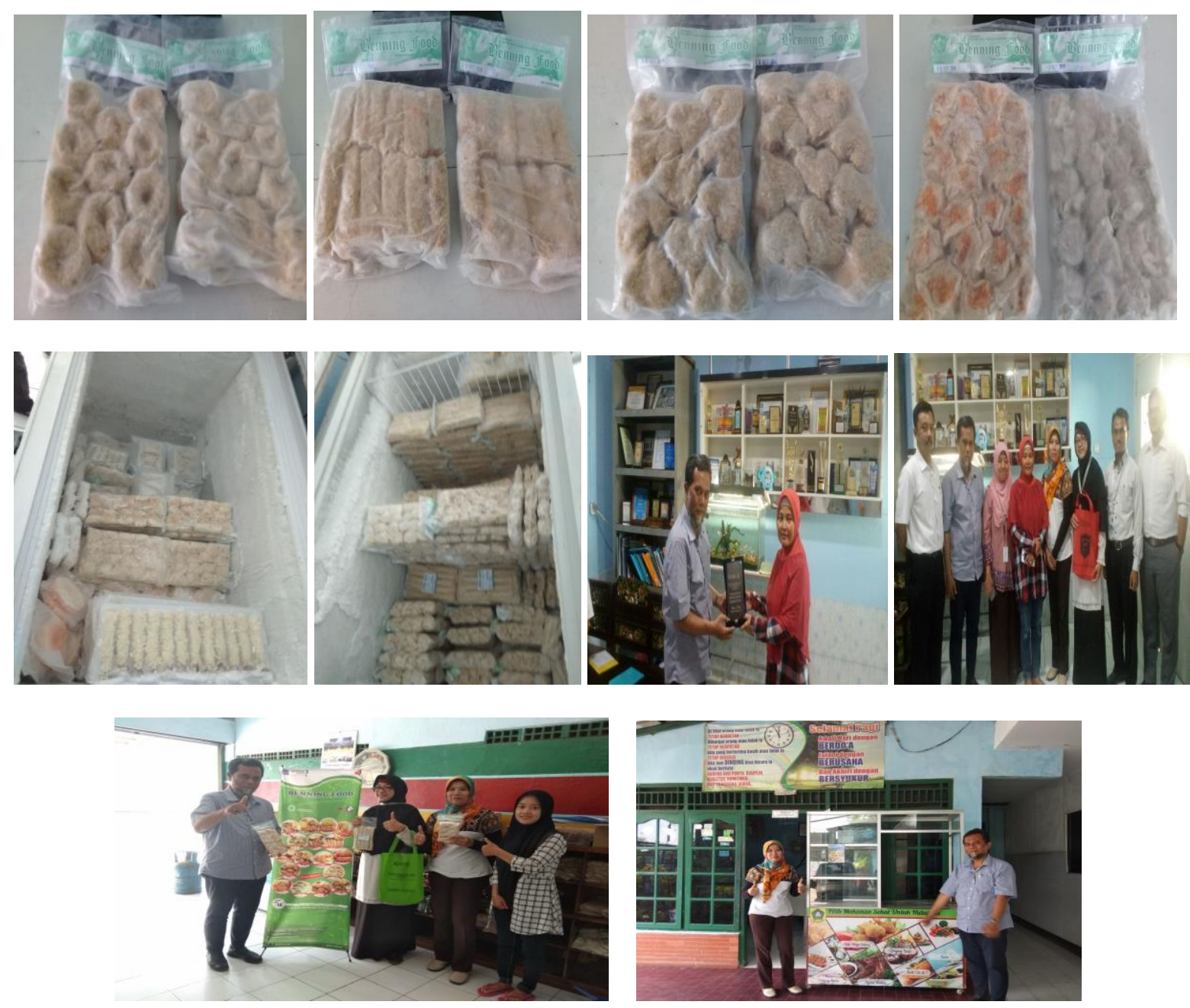

Gambar 1. Produk Hasil dari Kegiatan Pengabdian Kepada masyarakat

\section{E. KESIMPULAN}

Berdasar kegiatan dalam pengembangan aspek keuangan produk olahan ikan di CV. Bening Jati Anugrah telah berjalan dengan lancar dan memberikan kontribusi yang lebih kepada mitra. Dengan adanya pengabdian ini mitra dapat merasakan perbedaan sebelum dan setelah dilakukannya pendampingan yang dilakukan oleh tim pengabdian kepada masyarakat dari Politeknk APP Jakarta.

1. Kegiatan pengabdian pada masyarakat dapat memberikan manfaat langsung kepada para karyawan dalam menambah pengetahuan mengenai keuangan.

2. Dengan adanya pendampingan selama dilakukanya pengabdian kepada masyarakat ini mitra merasa lebih percaya diri untuk bersaing dengan UKM sejenis karena telah memiliki system informasi keuangan yang lebih modern yang berbeda dengan kompetitor serupa lainnya, walau masih tahap pembelajaran dan penerapan aplikasi. 
3. Selama periode kegiatan, terjadi kendala yang dialami oleh tim pengabdian masyarakat Politeknik APP Jakarta karena waktu pendampingan kita sama dengan waktu produksi industri olahan ikan yang dilakukan dari pagi sampai sore sehingga waktu kita tidak dapat maksimal. Kemudian yang kedua sifat mitra yang masih tertutup juga menghambat kita untuk pengambilan gambar kegiatan dan sebagainya.

\section{F. DAFTAR PUSTAKA}

Geminastiti K, dan Nella Nurlita. (2016). Ekonomi untuk Siswa SMA/MA Kelas XII Kelompok Peminatan Ilmu-Ilmu Sosial. Bandung : Penerbit Yrama Widya.

PT. Dharma Niaga bekerjasama dengan Dewan Penunjang Ekspor (DPE) dan Departemen Perdagangan RI. (1992). Buku Pedoman Peningkatan Mutu Komoditi Ekspor Indonesia. Jakarta : Penerbit PT Dharma Niaga.

Rangkuti F. (2008). Analisis SWOT Teknik Membedah Kasus Bisnis. Jakarta : Penerbit PT Gramedia Pustaka Utama.

Admin. (2017 ). CV. Bening Jati Anugrah: Dikutip 20 Juni 2019, dari http://hmtp.unpas.ac.id/tempat-kp/1043/.

Agung Utama. (2008). Aspek Keuangan Dalam Perencanaan Usaha: dikutip 25 Juni 2019, dari http://staffnew. uny.ac.id/upload/19741014200812 1001/ pengabdian/ Aspek+ Keuangan+ Dalam+Perencanaan+Usaha. pdf.

Benning Food. (2014). Liputan Majalah TROBOS 20 April 2013 Garap Perdagangan dan Olahan Produk Ikan: dikutip 20 Juni 2019 dikutip 20 Juni 2019, dari https://benningfood.wordpress.com/2014/05/07/67/.

Wikipedia.(2019). Parung Bogor Wikipedia Bahasa Indonesia: Dikutip 20 Juni 2019, dari https://id.wikipedia. org/wiki/Parung --Bogor.

Shelvi Mardiana, Iwang Gumilar dan Herman Hamdani. (2016). Analisis Prosfektif Usaha Produk Olahan Kaki Naga (Studi kasus di CV. Bening Jati Anugrah Kabupaten Bogor,). Jurnal Perikanan Kelautan Vol. VII No.2: Desember 2016 (22-28): Dikutip 25 Juni 2019, dari http://jurnal.unpad.ac.id/jpk/article/view/113 56/5207. 